\title{
Culture, Development and Self: The Work of Robert A. LeVine
}

\author{
Atwood D. Gaines ${ }^{1}$
}

Published online: 11 November 2015

(C) Springer Science+Business Media New York 2015

Dr. Robert A. LeVine has been honored this year (2015) in the pages of Culture, Medicine and Psychiatry. Now retired but mightily active, Professor LeVine is the Roy Edward Larsen Professor of Education and Human Development, Emeritus, at Graduate School of Education, Harvard University, USA.

\section{Education}

As indicated in my note in CMP 38(4), Professor LeVine is widely known for his work on the cultural dimensions of childhood and parenting across several continents. More recent work links maternal schooling with child health in Nepal. Dr. LeVine is an education and psychological/psychiatric (analytic) anthropologist and specialist in human development. As is the custom now for those honored by CMP, an accounting of Dr. LeVine's work is here presented in this the final CMP number of the year, i.e., volume 39, number 4.

Born in New York City, Dr. LeVine was educated at the University of Chicago (BA in 1951, MA 1953). He took his PhD in Social Anthropology from Harvard in 1958. He returned for psychoanalytic training to Chicago, where he earned a Certificate from the Chicago Institute for Psychoanalysis in 1971.

Atwood D. Gaines

atwood.gaines@case.edu

1 Case Western Reserve University, Cleveland, USA 


\section{Academic Positions}

Professor LeVine, or Bob as he is known, has held a variety of academic positions. He began his professorial career as an Instructor (later Assistant Professor) of Anthropology and Political Science at Northwestern University (the years 1958-1960). He was then called to an Assistant Professorship of Human Development, Anthropology and Psychiatry at the University of Chicago. He served in these posts from 1960 to 1976 during which he rose to full Professor. Subsequently, he was called to Harvard University where he was named Roy E. Larsen Professor of Education and Human Development during in the years 1976-1998. He was named Emeritus in 1998. Bob served as Chair, Human Development and Psychology in the Harvard Graduate School of Education from 1977 to 1980 and again from 1985 to 1989.

Fortunately for the discipline and its students, Bob also traveled and served as a Visiting Professor after his 'retirement.' He was Distinguished Visiting Professor, University of Hong Kong, 2001-2002, and the Lun Visiting Lecturer at the Chinese University of Hong Kong in 1994. He was Visiting Professor of Anthropology at Boston University, 2007-2009, and most recently, Visiting Professor of Comparative Human Development at the University of Chicago in the spring of 2008, thus completing a circle of career and educational venues. The person and work of Bob LeVine has been the recipient of numerous awards, which is not surprising given the breadth and depth of his career.

\section{Awards and Fellowships}

The plethora of notices of Bob's life and work include his inclusion in Phi Beta Kappa and Sigma Xi. From 1962 through 1967 LeVine held a Research Career Development Award from the National Institute of Mental Health (NIMH). Subsequently, he received a Research Scientist Award from NIMH that continued until 1976.

He was a Fellow at the Center for Advanced Study in Behavioral Sciences at Stanford for the 1971-1972 year. He was elected to membership in the National Academy of Education in 1979 and served as its Secretary/Treasurer for several years (1988-1993).

Bob was elected President of Society for Psychological Anthropology in 1980 and served the term to 1981. In 1989, he was elected as a Fellow of the American Academy of Arts and Sciences. Among his many other honors, we should note the following and their relevant dates:

- Spencer Senior Scholar Award, Spencer Foundation, 1990.

- Fellow, Swedish Collegium for Advanced Study in the Social Sciences, Uppsala, 1992-1993

- Career Contribution Award, Society for Psychological Anthropology, 1997

- Award for Distinguished Contributions to Educational Research, American Educational Research Association, 2001 
- John Simon Guggenheim Memorial Fellow, 2004-2005

Certainly, Bob has served in a number of other capacities for various groups. These services include membership in the Board of Directors of the Social Science Research Council (SSRC) from 1978 through 1984. He served as SSRC Secretary from 1978 to 1979 and as its Chairman from 1980 to 1983 . In addition we note the following memberships:

Member, Board of Trustees, Shady Hill School, Cambridge, MA, 1980-1983

Member, National Academy of Sciences panels:

Fertility Determinants, 1981-1984

Child Care Policy, 1987-1989

Early Childhood Pedagogy, 1998-2000

Member, Behavioral Sciences Committee, Yale University Council, 1982-1986

Member, Board of Directors, Spencer Foundation, 1991-2001

Member, National Research Advisory Panel for the Head Start Transition Project, 1991-1995

Consultant to Third International Mathematics and Science Study (TIMSS), National Center for Educational Statistics, U.S. Dept. of Education, 1995-1997

These awards and memberships make manifest Bob's dedication to service as well as his highly regarded scholarship. We also see his many hats, psychological anthropologist, education specialist, child scholar, and synthesizing social scientist.

\section{Anthropological Field Research}

Bob LeVine's primary research was been among the Gusii of Kenya. He has spent several long-term research sojourns among them, i.e., 1955-1957, 1964, 1974-1976. He has also worked in West Africa, in Nigeria among the Yoruba (1961-1962 and again in 1963) and with the Hausa (1969). And he has considered notions of the good child in Japan (with White 1986) and also Japanese Frames of Mind (Shimizu and LeVine 2001) applying a cultural approach to notions of human development.

\section{Robert A LeVine: Publications}

\section{Book Length Works}

Dr. LeVine is well known to all psychological and psychiatric anthropologists and, indeed, trained many of them, including one of CMP's Consulting Editors, Dr. Eileen Anderson-Fye. He has researched a number of topical fields and has ranged widely around the globe, work that has resulted in many books and edited volumes. A major focus of his has been the cultural aspects of parenthood and child development in Africa, Asia and Latin America, and other societies. His most recent work has concerned the effect of maternal schooling and literacy on reproduction and on child health care in Nepal. This award-winning work considers the effect of 
literacy among women that in turn affects the health status of their children (see LeVine, LeVine Schnell-Anzola et al. 2012).

Bob's first book (with BB LeVine, 1963) focused on the Nyansongo, a Gusii community in Kenya. This work was one of the volumes in Beatrice Whiting's Six Cultures: Studies of Child Rearing series. This Nyansongo community was also the focus of his first published articles (LeVine 1958, 1959a, b). Many subsequent works analyze child development and child rearing in diverse societies (e.g., LeVine, Dixon LeVine et al. 1994; LeVine 2003) but also, given his clear understanding of the relational nature of the development of the child, he has considered the nature of parental behaviors including gender roles and women's characteristics in context and in their relation to children (e.g., LeVine, Miller and West 1988: LeVine 2003; LeVine, LeVine and Schnell-Anzola et al. 2012). And let us not forget the domestic context in terms of the actual structures in which socialization occurs! (see article by LeVine and LeVine 1991). LeVine's work on socialization, human development and parenting are incomparable and were and are models for the fields. Not an equilibrium theorist, LeVine has also considered conflict in various settings as relates to notions of (ethnic) selves (e.g., LeVine and Campbell 1972) and colonialism (see article, 1959a).

In our honoree's second book, the well-known Dreams and Deeds: Achievement Motivation in Nigeria (with EH Strangman and LH Unterberger 1966), he shows a concern for the unconscious as expressed in dreams and its influence on conscious motivation, thus invoking his psychoanalytic training in his ethnography.

LeVine's work has shown a high degree of synthesis of disciplines, prefiguring the direction of Millennial Medical Anthropology that has appeared in this Journal. He combines sociocultural anthropological theory and its ethnographic tradition with psychoanalysis, psychology (e.g., personality theory, socialization, self theory, cognitive development), human development, adolescent studies, reproductive health and practices, education theory, culture change theory, conflict theory, and gender and gender roles scholarship. This synthesis gives richness to his work that is rare among scholars, as many mistake a limited focus and or method as the royal road to deep understanding. Levine understands that humans are complex and multifaceted and their study requires attention to many dimensions of human experience and action as well as a relational perspective (see LeVine 1973).

Some very noteworthy works of Bob's bear mentioning. These include his Culture, Behavior and Personality (1973) and its clear formulation of notions of the relational nature of culture, personality and analytic understandings of their relationship and consequences for action (1973). Also of great importance is his volume edited with Richard Shweder, Culture Theory: Essays on Mind, Self and Emotion (Shweder and LeVine 1984). His contribution to that volume is one of the clearest expositions of why ethnographic knowledge is incomparable and trumps empiricist forms of analysis of decontexted 'variables' (LeVine 1984). Other of his books include Childcare and Culture: Lessons from Africa, (1994) and Human Conditions: the Cultural Basis of Educational Development (with M. I. White) (1986). A full list of Professor LeVine's books is below. We conclude our celebration with the up to date list of Dr. LeVine's articles and book chapters. Both 
lists of references may serve as a resource for scholars in the many relevant disciplines of his work.

\section{Books by Robert A LeVine}

LeVine, R.A. \& LeVine, B.B. (1963). Nyansongo: A Gusii community in Kenya. In B. Whiting (ed.), Six Cultures: Studies of Child Rearing. New York: John Wiley \& Sons. (Published as a separate paperbound volume, 1966. Reprinted by Krieger, 1977).

LeVine, R.A., with the assistance of Strangman, E.H. \& Unterberger, L.H. (1966). Dreams and Deeds: Achievement Motivation in Nigeria. Chicago: University of Chicago Press.

LeVine, R.A. \& Campbell, D.T. (1972). Ethnocentrism: Theories of Conflict, Ethnic Attitudes, and Group Behavior. New York: John Wiley.

LeVine, R.A. (1973, 2nd Edition 1982). Culture, Behavior, and Personality: An Introduction to the Comparative Study of Psychosocial Adaptation. Chicago: Aldine. (Second Edition: New York: Aldine de Gruyter, 1982). (First Edition Spanish translation, 1977).

LeVine, R.A., ed. (1974). Culture and Personality: Contemporary Readings. Chicago: Aldine.

Shweder, R. \& LeVine, R.A., eds. (1984). Culture Theory: Essays on Mind, Self and Emotion. Cambridge, U.K.: Cambridge University Press.

LeVine, R.A. \& White, M.I. (1986). Human Conditions: The Cultural Basis of Educational Development. London: Routledge \& Kegan Paul.

LeVine, R.A., Miller, P. \& West, M.M., eds. (1988). Parental Behavior in Diverse Societies. New Directions for Child Development Sourcebook No. 40. San Francisco: Jossey-Bass.

LeVine, R.A., Dixon, S., LeVine, S., Richman, A., Keefer, C., Leiderman, P.H. \& Brazelton, T.B. (1994). Child Care and Culture: Lessons from Africa. New York: Cambridge University Press.

Shimizu, H. and LeVine, R.A., eds. (2001). Japanese Frames of Mind: Cultural Perspectives on Human Development. New York: Cambridge University Press.

LeVine, R.A. (2003). Childhood Socialization: Comparative Studies of Parenting, Learning and Educational Change. CERC Monograph No. 20. Hong Kong: Comparative Education Research Centre, University of Hong Kong.

LeVine, R.A. and New, R.S., eds. (2008). Anthropology and Child Development: A Cross-Cultural Reader. Malden, MA: Blackwell Publishers. New York: WileyBlackwell.

LeVine, R.A., ed., (2010). Psychological Anthropology: A Reader on Self in Culture. Malden, MA: Wiley-Blackwell.

LeVine, R.A., LeVine, S.E., Schnell-Anzola, B., Rowe, M. \& Dexter, E. (2012). Literacy and Mothering: How Women's Schooling Changes the Lives of the World's Children. New York: Oxford University Press. (Winner of the 2013 Eleanor E. Maccoby Book Prize of the American Psychological Association.) 


\section{Robert A. LeVine: Articles and Book Chapters}

LeVine, R.A. (1958). Omoriori: Smeller of witches, Natural History, 67, 142-147.

LeVine, R.A. (1959a). An attempt to change the Gusii initiation cycle. Man, 59,117-120.

LeVine, R.A. (1959b). Gusii sex offenses: A study in social control. American Anthropologist, 61, 965-990.

LeVine, R.A. (1959c). Anti-European violence in Africa: A comparative analysis. Journal of Conflict Resolution, 3, 420-429.

LeVine, R.A. (1960a). The internalization of political values in stateless societies. Human Organization, 19, 51-58.

LeVine, R.A. (1960b). The role of the family in authority systems: A crosscultural application of stimulus-generalization theory. Behavioral Science, 5, 291-296.

LeVine, R.A. (1961). Anthropology and the Study of Conflict: An introduction. Journal of Conflict Resolution, 5, 3-15.

Campbell, D.T. \& LeVine, R.A. (1961). A proposal for cooperative cross-cultural research on ethnocentrism. Journal of Conflict Resolution, 5, 82-108.

LeVine, R.A. (1961). Africa. In F.L.K. Hsu (ed.), Psychological Anthropology. Homewood, IL: Dorsey Press.

LeVine, R.A. (1962). Wealth and Power in Gusiiland. In P.J. Bohannon (ed.), Markets in Africa. Evanston, IL: Northwestern University Press.

LeVine, R.A. \& LeVine, B.B. (1962). Studying child rearing and personality development in an East African community. Anthropology and Africa Today. Transaction of the New York Academy of Sciences, 96, 491-690.

LeVine, R.A. (1962). Witchcraft and co-wife proximity in Southwestern Kenya. Ethnology, 1, 39-45.

LeVine, R.A. \& Sangree, W.H. (1962). The diffusion of age group organization in East Africa: A controlled comparison. Africa, 32, 97-110.

LeVine, R.A. (1963). Political socialization and culture change. In C. Geertz (ed.), Old

Societies and New States. NY: The Free Press of Glencoe.

LeVine, R.A. (1963). Witchcraft and sorcery in a Gusii community. In J. Middleton \& E.H. Winter (eds.), Witchcraft and sorcery in East Africa. London: Routledge, Kegan Paul.

LeVine, R.A. (1963). Child-rearing in Subsaharan Africa: An interim report. Bulletin of the Menninger Clinic.

LeVine, R.A. (1963). Behaviorism in psychological anthropology. In J.M. Wepman and R.W. Heine (eds.), Concepts of Personality. Chicago: Aldine Press.

LeVine, R.A. (1963). Culture and personality. In B.J. Siegel (ed.), Biennial Review of Anthropology. Stanford: Stanford University Press.

LeVine, R.A. (1964). The Gusii family. In R.F. Gray and P.H. Gulliver (eds.), The Family Estate in Africa. Boston: Boston University Press.

LeVine, R.A. (1965). Socialization, social structure, and intersocietal images. In H.C. Kelman (ed.), International Behavior: A Social Psychological Analysis. New York: Holt, Rinehart, and Winston. 
LeVine, R.A. (1965). Intergenerational tensions and extended family structures in Africa. In E. Shanas \& G.F. Streib (eds.), Social Structure and the Family: Generational Relations. New Jersey: Prentice-Hall.

LeVine, R.A. (1966). Outsiders' judgements: An ethnographic approach to group differences in personality. Southwestern Journal of Anthropology, 22, 101-116.

LeVine, R.A. (1966). American college experiences as a socialization process. In T.M. Newcomb (ed.), The Study of College Peer Groups. NORC Monograph in Social Research Studies. Chicago: Aldine Press.

LeVine, R.A. (1966). Toward a psychology of populations: The cross-cultural study of personality. Human Development, 9, 30-46.

LeVine, R.A. (1966). Sex roles and economic change in Africa. Ethnology, 5 (2), 186-193.

Sawyer, J. \& LeVine, R.A. (1966). Cultural dimensions: A factor analysis of the world ethnographic sample. American Anthropologist, 68, 708-731.

LeVine, R.A. (1966). The psychological transition to humanity. In The Study of Early Man. Chicago: Anthropology Curriculum Study Project, American Anthropological Association.

LeVine, R.A., Owen, C.R. \& Klein, N.H. (1967). Father-child relationships and changing lifestyles in Ibadan, Nigeria. In H.M. Miner (ed.), The City in Modern Africa. New York: Praeger.

Campbell, D.T. \& LeVine, R.A. (1968). Ethnocentrism and intergroup relations. In R. Abelson, E. Aronson, W. Mcguire, T. Newcomb, M. Rosenberg \& P. Tannenbaum (eds.), Theories of Cognitive Consistency. Chicago: Rand-McNally.

LeVine, R.A. (1969). Culture, personality, and socialization: An evolutionary view. In D. Goslin (ed.), The Handbook of Socialization Theory and Research. Chicago: Rand-McNally.

LeVine, R.A. (1969). Uneven development as a unifying perspective on world affairs. In J. Becker (ed.), An Examination of Objectives, Needs, and Priorities in International Education in U.S. Secondary and Elementary Schools. New York: Foreign Policy Association.

LeVine, R.A. (1970). Cross-cultural study in child psychology. In P.H. Mussen (ed.), Carmichael's Manual of Child Psychology. New York: John Wiley.

LeVine, R.A. (1970). Personality and change. In J. Paden \& E. Soja (eds.), The African Experience, Volume I. Evanston, IL: Northwestern University Press.

Campbell, D.T. \& LeVine, R.A. (1970). Field manual anthropology. In R. Cohen \& R. Naroll (eds.), The Handbook of Method in Cultural Anthropology. Garden City, NY: Natural History Press.

LeVine, R.A. (1970). Research design in anthropological field work. In R. Cohen \& R. Naroll (eds.), The Handbook of Method in Cultural Anthropology. Garden City, NY: Natural History Press.

LeVine, R.A. (1970). Psychosocial studies in Africa. African Studies Review, 13, 105-111.

LeVine, R.A. (1971). The psychoanalytic study of lives in natural social settings. Human Development, 14, 100-109.

Nerlove, S.B. \& LeVine, R.A. (1972). Population growth in a Kenya community. American Anthropologist, 74, 408-410. 
LeVine, R.A. (1973). Patterns of personality in Africa. Ethos, 1, 123-152.

LeVine. R.A. (1974). Parental goals: A cross-cultural view. Teachers College Record, 76, 226-239.

LeVine, R.A. \& Price-Williams, D.R. (1974). Children's kinship concepts: Cognitive development and early experience among the Hausa. Ethnology, 13, 25-44.

LeVine, R.A. (1974). Comment on the note by Super and Harkness. Ethos, 2, 382-386.

Shweder, R.A. \& LeVine, R.A. (1976). Dream concepts of Hausa children: A critique of the 'doctrine of invariant sequence' in cognitive development. In $\mathrm{T}$. Schwartz (ed.), Socialization as Cultural Communication. Berkeley, CA: University of California Press.

LeVine, R.A. (1977). Child rearing as cultural adaptation. In P.H. Leiderman, S. Tulkin \& A. Rosenfeld (eds.), Culture and Infancy: Variations in the Human Experience. New York: Academic Press.

LeVine, R.A. (1978). Western schools in non-Western societies: Psychosocial impact and cultural response. Teachers College Record, 749-755.

LeVine, R.A. (1978). Comparative notes on the life course. In T. Hareven (ed.), Transitions: The Family and the Life Course in Historical Perspective. New York: Academic Press.

LeVine. R.A. (1978). Adulthood and aging in cross-cultural perspective. Items, 31/32, 1-20.

LeVine, Sarah E., in collaboration with Robert LeVine. (1979). Mothers and Wives: Gusii Women of East Africa. Chicago: University of Chicago Press.

LeVine, R.A. (1980). Adulthood among the Gusii of Kenya. In N. Smelser \& E. Erikson (eds.), Themes of Love and Work in Adulthood. Cambridge, MA: Harvard University Press.

LeVine, R.A. (1980). A cross-cultural perspective on parenting. In M. Fantini and R. Cardenas (eds.), Parenting in a Multicultural Society. New York: Longman.

LeVine, R.A. (1980). Influences of women's schooling on maternal behavior in the Third World. Comparative Education Review, 24, Supplement, 78-105.

LeVine, R.A. (1980). Anthropology and child development. New Directions for Child Development, 8, 71-86.

LeVine, R.A. (1981). Knowledge and fallibility in anthropological field research. In M. Brewer \& B. Collins (eds.), Scientific Inquiry and the Social Sciences. San Francisco: Jossey-Bass.

LeVine, R.A. (1982). Gusii funerals: Meanings of life and death in an African community. Ethos, 10, 26-65.

LeVine, R.A. (1982). The self and its development in an African society. In B. Lee (ed.), New Approaches to the Self. New York: Plenum.

Dixon, S., LeVine, R.A. \& Brazelton, T.B. (1982). Malnutrition: A closer look at the problem in an East African village. Developmental Medicine and Child Neurology, 24, 670-685.

LeVine, R.A. (1983). Fertility and child development: an anthropological approach. In D. Wagner (ed.), Child Development and International Development: 
Research-Policy Interfaces, New Directions for Child Development, No. 20. San Francisco: Jossey-Bass.

Lutz, C. \& LeVine, R.A. (1983). Culture and intelligence in infancy: An ethnopsychological view in origins of intelligence, infancy, and early childhood. In M. Lewis (ed.), Origins of Intelligence: Infancy and Early Childhood (2nd edition). New York: Plenum Press.

LeVine, R.A. \& Scrimshaw, S. (1983). Effects of culture on fertility: Anthropological contributions. In R. Bulatao \& R. Lee (eds.), Determinants of Fertility in Developing Countries, Vol. 2. New York: Academic Press.

LeVine, R.A. (1984). Properties of culture: An ethnographic view. In R. Shweder \& R.A. LeVine (eds.), Culture Theory: Essays on Mind, Emotion, and the Self. New York: Cambridge University Press.

Dixon, S.D., LeVine, R.A. \& Brazelton, B.T. (1984). Mother-child interaction around a teaching task: An African-American comparison. Child Development, 55, 1252-1264.

LeVine, S.E. \& LeVine, R.A. (1984). Age, gender and the demographic transition: The life course in agrarian societies. In A. Rossi (ed.), Gender and the Life Course. Hawthorne, NY: Aldine Publishing Co.

LeVine, R.A. (1984). Maternal behavior and child development in high-fertility populations. Fertility Determinants Notes, No. 2. New York: The Population Council.

White, M.I. \& LeVine, R.A. (1986). What is an Ii ko (good child)? In H. Stevenson, H. Azuma \& K. Hakuta (eds.), Child Development and Education in Japan. New York: W.H. Freeman.

LeVine, R.A., LeVine, S.E., Richman, A. \& Sunderland Correa, C. (1987). Schooling and maternal behavior in a Mexican city: The effects on fertility and child survival. Fertility Determinants Research Notes, No. 16.

LeVine. R.A. (1987). Women's schooling, patterns of fertility and child survival. Educational Researcher, 16, 21-27.

LeVine, R.A. (1990). Enculturation: A biosocial perspective on the development of self. In D. Cicchetti (ed.), The Development of the Self. Chicago: University of Chicago Press.

Richman, A., LeVine, R.A., New, R., Howrigan, G., Welles, B. \& LeVine, S.E. (1988). Cultural differences in mother-infant interaction: evidence from a fiveculture study. In R.A. LeVine, M.M. West \& P. Miller (eds.), Parental Behavior in Diverse Societies, New Directions for Child Development, No. 40. San Francisco: Jossey-Bass.

LeVine, R.A. \& LeVine, S.E. (1988). Parental strategies among the Gusii of Kenya. In R.A. LeVine, M. West \& P. Miller (eds.), Parental Behavior in Diverse Societies, New Directions for Child Development, No. 40. San Francisco: JosseyBass.

LeVine, R.A. (1990). Infant environments in psychoanalysis: A cross-cultural view. In R. Shweder, G. Herdt \& J. Stigler (eds.), Cultural Psychology: and Human Development. New York: Cambridge University Press.

LeVine, R.A., LeVine, S.E., Richman, A., Tapia Uribe, F.M., Sunderland Correa, C. \& Miller, P.M. (1991). Women's schooling and child care in the demographic 
transition: A Mexican case study. Population and Development Review, 17, 459-496.

LeVine, R.A., and LeVine, S.E. (1991). House design and the self in an African culture. In L.B. Boyer and R. Boyer (eds.), The Psychoanalytic Study of Society, 16, 87-109.

Richman, A., Miller, P.M. and LeVine, R.A. (1992). Cultural and educational variations in maternal responsiveness. Developmental Psychology, 28, 614-621.

LeVine, R.A., LeVine, S.E., Richman, A., Tapia Uribe, F.M. and Sunderland Correa, C. (1994). Schooling and survival: The impact of education on reproduction and health in the Third World. In A. Kleinman, L.C. Chen and N. Ware (eds.), Health and Social Change in International Perspective. Boston: Harvard University Press.

LeVine, R.A., Dexter, E., Velasco, P., LeVine, S., Joshi, A., Stuebing, K., and Tapia-Uribe, F.M. (1994). Maternal literacy and health care in three countries: a preliminary report. Health Transition Review, 4:2, 186-191.

Tapia Uribe, F.M., LeVine, R.A. and LeVine, S.E. (1994). Maternal behavior in a Mexican community: The changing environments of children. In P. Greenfield and R. Cocking (eds.), Cross Cultural Roots of Minority Child Development. Hillsdale, NJ: Lawrence Erlbaum Associates.

LeVine, R.A. (1995). Psychoanalysis. In D. Levinson and M. Ember (eds.), The Encyclopedia of Cultural Anthropology. New York: Henry Holt.

LeVine, R.A., Miller, P.M., Richman, A.L. \& LeVine, S.E. (1996). Education and mother-child interaction: A Mexican case study. In S. Harkness and C. M. Super, eds., Parents' Cultural Belief Systems. New York: Guilford.

LeVine, R.A. (1997). Mother-infant interaction in cross-cultural perspective. In N. Segal, G. Weisfeld and C. Weisfeld (eds.), Uniting Psychology and Biology: Integrative Perspectives on Human Development. Washington, DC: American Psychological Association.

LeVine, R.A. (1997). Childhood and socialization. In J. Middleton (ed.), The Encyclopedia of Subsaharan Africa. New York: Scribner's.

LeVine, R.A. (1997). Science and scientism in anthropology. Anthropology Newsletter.

Hakansson, T.H. and LeVine, R.A. (1997). Gender and life course strategies among the Gusii. In T. Weisner, C. Bradley and P. Kilbride (eds.), African Families and the Crisis of Social Change. Westport, Conn.: Bergin and Garvey.

Shweder, R.A., Goodnow, J., Hatano, G., LeVine, R.A., Markus, H., and Miller, P. (1998). The cultural psychology of development: One mind, many mentalities. In R.M. Lerner (ed.), Vol. 1, Theoretical Models of Human Development, The Handbook of Child Psychology, 5th edition (edited by W. Damon). New York: Wiley

LeVine, R.A. (1998). Culture and personality. In T. Barfield (ed.), Dictionary of Anthropology. Cambridge, MA: Blackwell.

LeVine, R.A. (1998). Education. In T. Barfield (ed.), Dictionary of Anthropology. Cambridge, MA: Blackwell. 
LeVine, R.A. and LeVine, S.E. (1998). Fertility and maturity in Africa: Gusii parents in middle adulthood. In R.A. Shweder (ed.), Welcome to Middle Age! (And Other Cultural Fictions). Chicago: University of Chicago Press.

Sharma, D. and LeVine, R.A. (1998). Child care in India: A comparative developmental view of infant social environments. In D. Sharma and K. W. Fischer (eds.), Socioemotional Development Across Cultures. New Directions for Child Development No. 81. San Francisco: Jossey-Bass.

LeVine, R.A. (1999). Child psychology and anthropology: An environmental perspective. In C. Panter-Brick (ed.) The Anthropology of Childhood: Biosocial Perspectives. Cambridge, U.K.: Cambridge University Press.

LeVine, R.A. (1999) Literacy and population change. In D. Wagner, R. Venezky and B. Street (eds.), Literacy: An International Handbook. Boulder, Colo.: Westview Press.

LeVine, R.A. (2000). John W.M. Whiting (1908-1999). American Anthropologist

LeVine, R.A. (2000). Epilogue. In A. Robben and M. Suarez-Orozco (eds.) Cultures Under Siege. Cambridge, U.K.: Cambridge University Press.

LeVine, R.A., LeVine, S.E. and Schnell, B. (2001). "Improve the women”: Mass schooling, female literacy and worldwide social change. Harvard Educational Review 71 (1): 1-50.

LeVine, R.A. (2001). Culture and personality studies, 1918-1960: Myth and history. Journal of Personality 69 (6): 803-818.

LeVine, R.A. and LeVine, S.E. (2001). The schooling of women: maternal behavior and child environments. Ethos 29: 259-270.

LeVine, R.A. and Norman, K. (2001) The infant's acquisition of culture: infantmother attachment re-examined from an anthropological point of view. In C. Moore and H. Mathews (eds.) The Psychology of Cultural Experience. New York: Cambridge University Press.

LeVine, R.A. (2002). Contexts and culture in psychological research. In J. Bempechat and J.G. Elliott (eds.), Learning in Culture and Context: Approaching the Complexities of Achievement Motivation in Student Learning. New Directions for Child and Adolescent Development, no. 96. Jossey-Bass Education Series. New York: John Wiley \& Sons.

LeVine, R.A. (2002). Populations, communication and child development. Human Development 45: 291-293.

LeVine, R.A. (2004). Challenging expert knowledge: Findings from an African study of child care and infants. In U. Gielen and J. Roopnaraine (eds.), Childhood and adolescence: Cross-cultural studies and applications, Vol. 1. Westport, CT: Greenwood Publishing Group.

LeVine, R.A., LeVine, S.E., Rowe, M.L. \& Schnell-Anzola, B. (2004). Maternal literacy and health behavior: A Nepalese case study. Social Science and Medicine 58 (4) 863-877.

Schnell-Anzola, B., Rowe, M.L. \& LeVine, R.A. (2005). Literacy as a pathway between schooling and health-related communication skills: A study of Venezuelan mothers. International Journal of Educational Development 25: 19-37. 
Rowe, M.L., Thapa, B.J., LeVine, S.E., LeVine, R.A. and Tuladhar, S. (2005). How does schooling influence health practices in Nepal? Comparative Education Review 49: 512-533.

LeVine, R.A. (2005). Coded communications: Symbolic psychological anthropology. In R.A. Shweder and B. Good (eds.), Clifford Geertz by his Colleagues. Chicago: University of Chicago Press.

LeVine, R.A. (2005). Levy's Tahitians: A model for ethnopsychology. Ethos 33: 475-479.

LeVine, R.A. (2007) Ethnographic studies of childhood: A historical overview. American Anthropologist 109: 247-260.

LeVine, R.A. (2007). Anthropological foundations of cultural psychology. In S. Kitayama and D. Cohen (eds.), Handbook of Cultural Psychology. New York: Guilford.

LeVine, R.A. (2007). The global spread of women's schooling: Effects on learning, literacy, health and children. In M. Suarez-Orozco (ed.), Globalization and Learning. Berkeley, CA: University of California Press.

LeVine, R.A. (2007). Education. In John Middleton (ed.), Encyclopedia of SubSaharan Africa, 2nd ed. New York: Scribners.

LeVine, R.A. (2007). Infancy and early childhood. In John Middleton (ed.), Encyclopedia of Sub-Saharan Africa, 2nd ed. New York: Scribners.

LeVine, R.A. (2007). Foreword. In Heidi Keller, Cultures of Infancy. Hillsdale, NJ: Lawrence Erlbaum Associates

LeVine, R.A. (2007). Afterword. In Helena Wulff (ed.), The Emotions: A Cultural Reader. Oxford, UK: Berg.

LeVine, R.A. (2009). Child: Historical and cultural perspectives. In Richard A. Shweder (ed.), The Child: An Encyclopedic Companion. Chicago: University of Chicago Press.

LeVine, R.A. (2009). Socialization of the child. In Richard A. Shweder (ed.), The Child: An Encyclopedic Companion. Chicago: University of Chicago Press.

LeVine, R.A. and Rowe, M. (2009). Maternal literacy and child health in less developed countries: evidence, processes and limitations. Journal of Developmental and Behavioral Pediatrics 30: 340-349.

LeVine, R.A. (2010) Plasticity and variation: Cultural influences on parenting and early child development within and across populations. In Carol Worthman, Paul Plotsky, Daniel Schechter and Constance Cummings (eds.), Formative Experiences: The Interaction of Caregiving, Culture and Developmental Psychobiology. New York: Cambridge University Press.

LeVine, R.A. (2010). Foreword. In David E. Lancy, John Bock and Suzanne Gaskins (eds.), The Anthropology of Learning in Childhood. Lanham, MD: AltaMira Press.

LeVine, R.A. (2010). Commentary: From the mother's point of view. In Special Issue: Mothering as Everyday Practice. Ethos 38: 458-460.

LeVine, R.A. (2010). Protective environments in Africa and elsewhere. In Barry M. Lester and Joshua D. Sparrow (eds.), Nurturing Children and Families: Building on the Legacy of T. Berry Brazelton. Malden, MA: Blackwell, pp. 132-140. 


\section{Honors for Robert A LeVine}

\section{Conclusion}

We conclude the survey of Dr. LeVine's work with a few more words. As is evident from the foregoing, Bob has been a tireless researcher and teacher who has done much to advance the practice of synthesis (rather than a layering or intersecting) of heretofore disparate theories and disciplines. His legacy, to which he is yet adding, is exceptional. For this we at CMP are ourselves honored to be able to do honor to Bob, but also for another reason; that is, because he is truly the classic example of the old descriptor, "a scholar and a gentleman."

\section{Previous CMP Honorees:}

Margaret Lock (2012)

Renée Fox (2013)

Robert Edgerton (2014) 